\title{
HATE CRIMES AGAINST BLACK LESBIAN SOUTH AFRICANS: WHERE RACE, SEXUAL ORIENTATION AND GENDER COLLIDE (PART I)
}

Kamban Naidoo

$B A$ LLB LLM

Senior Lecturer, Criminal and Procedural Law University of South Africa (UNISA)

Michelle Karels

LLB LLM

Senior Lecturer, Criminal and Procedural Law University of South Africa (UNISA)

\section{SUMMARY}

This article, which is the first of a two-part submission, examines the phenomenon of gender-based violence against black lesbian South Africans. The course and incidence of gender-based violence against black lesbians are tracked from both media articles and academic contributions. The various forms of criminal conduct which characterize the phenomenon (including "corrective rape" and murder) are also examined. The article concludes with a limited causal explanation for what has emerged as a serious social problem in present-day South Africa necessitating government intervention in the form of a recently announced Task Team.

\section{A INTRODUCTION}

The phenomenon of gender-based violence, ${ }^{1}$ particularly against adult, heterosexual $^{2}$ women, has been well researched and documented in South

There is no consensus on the meaning of the term "gender-based violence". Some academics are of the view that it should encompass all forms of violence that are perpetrated as a result of a person's gender identity. Viewed in this sense, it could therefore also include violence against men. Within the context of this article, however, the view of Mkhize, Bennet, Reddy and Moletsane The Country We Want to Live in: Hate Crimes and Homophobia in the Lives of Black Lesbian South Africans (2010) is preferred. They opine that since the mid-1990s the term "gender-based violence" has replaced the term "violence against women" and refers to a range of violations suffered by women because of their gendered status. It could include rape, domestic assault, sexual harassment, incest, and 
Africa. ${ }^{3}$ However, gender-based violence against lesbian women ${ }^{4}$ has not been similarly acknowledged. Lesbian women in South Africa have been described as "a silent and invisible minority". This invisibility and silence can be ascribed in part to South Africa's patriarchal apartheid past in which lesbian women were "seldom a focus of the Apartheid State's attention", since most of the focus was on regulating inter-racial male homosexual relations. ${ }^{6}$

It was not until 2003 that sporadic print-media reports drew public attention to the fact that lesbian women, particularly black lesbians ${ }^{7}$ living in certain urban and suburban areas of South Africa, were "being raped, assaulted and victimised every day ... in an attempt to force a change in their sexual orientation". ${ }^{8}$ Media attention to this insidious and brutal form of gender-based violence was in no small part due to the activist work conducted by a limited number of civil-society organizations. Organizations such as the Forum for the Empowerment of Women and Behind the Mask had been conducting workshops and empowerment programmes on hate crimes $^{9}$ in Johannesburg townships since $2001 .{ }^{10}$

forced prostitution Mkhize et al The Country We Want to Live in: Hate Crimes and Homophobia in the Lives of Black Lesbian South Africans 17.

2 In the context of this submission "heterosexual" can be defined as "relating to sexual desire or sexual relations between people of the opposite sexes" or as "somebody who is attracted to members of the opposite sex".

3 Eg, Vogelman and Eagle "Overcoming Endemic Violence Against Women in South Africa" 199118 Social Justice 209 229; Dangor and Hoff "Women Abuse in South Africa: An Exploratory Study" 1998 4(2) Violence Against Women 125 152; and Jewkes, Penn-Kekana, Levin, Ratsaka and Schreiber "Prevalence of Emotional, Physical and Sexual Abuse of Women in Three South African Provinces" 2001 91(5) South African Medical Journal 421 428.

4 In the context of this article, the term "lesbian woman" refers to a homosexual woman whose identity could fall within a wide spectrum that includes the more masculine or "butch" lesbian woman who could refer to herself as a "lesbian man"; Muholi "Thinking Through Lesbian Rape" 200461 Agenda 117118 or as a "tommy boy"; and Morgan and Wieringa Tommy Boys, Lesbian Men and Ancestral Wives: Female Same-Sex Practices in Africa (2005) 1. It could also include the more feminine or "femme" lesbian woman, see Wells and Polders "Anti-gay Hate Crimes in South Africa: Prevalence, Reporting Practices and Experiences of the Police" 200667 Agenda 2028.

5 Wells and Polders 200667 Agenda 20.

6 Muholi "Mapping Our Histories: A Visual History of Black Lesbians in Post Apartheid South Africa" $2010 \mathrm{http}: / /$ www.zanelemuholi.com (accessed 2011-15-03). See also the now repealed Immorality Act 21 of 1950 , which prohibited mixed-race sexual relations and the Immorality Amendment Act 57 of 1969 which made sexual relations between a man and another man under the age of 19 a serious offence. See also Roman-Dutch common-law provisions declaring sodomy "the commission of an unnatural sex act". All the statutory laws have now been repealed and at present non-consensual sodomy is defined as rape in terms of The Criminal Law (Sexual Offences and Related Matters) Amendment Act 32 of 2007. Homosexual relations between consenting adults are no longer criminalized in South African law. The Roman-Dutch common-law provisions relating to sodomy were declared unconstitutional and invalid in the case of National Coalition for Gay and Lesbian Equality $v$ Minister of Justice (1998) ZACC 15.

7 The term "black" is used in its narrow sense to refer to black African people only.

8 Mufweba "Corrective Rape Makes You an African Woman" 2003 The Star http://www.iol.co.za (accessed 2011-03-09).

9 The term "hate crime" was coined in the 1980s by journalists and policy advocates to describe a number of crimes committed against African Americans, Asians and Jews Shively and Mulford "Hate Crime in America: The Debate Continues" 2007257 National 
One positive consequence of the activist work and media attention was the inclusion and mainstreaming, in 2006, of violence against lesbian women as a "keyzone" of gender-based violence against women in South Africa's observance of 16 Days of Activism for no Violence against Women and Children. ${ }^{11}$

The violence being perpetrated against black lesbian women in South Africa is indeed ironic given the present legal and political environment of Constitutional protections and adherence to a number of international treaties that provide for the protection of women, irrespective of their sexual orientation.

This article consists of two complementary parts. Part I examines the phenomenon of gender-based violence against black lesbian women in the South African context, with specific focus on its course and incidence, and provides a limited causal explanation of this phenomenon. Part II examines the existing legal framework, with particular emphasis on criminal law, and explores possible legal reforms and reforms that extend beyond the ambit of the law. Conclusions and recommendations will be included in Part II of the submission.

\section{B METHOD(S)}

This submission is based on a literature study based on both academic and traditionally non-academic sources. Academic sources consisting of academic literature (journal articles and books) were referred to. Owing to the paucity of academic literature on gender-based violence against black lesbian women in South Africa from a legal perspective, non-academic sources such as anecdotal evidence from the print media and the reports of civil-society organizations were also consulted. These reports are principally based on the narratives or testimonies of black lesbian women who survived violent and abusive attacks.

Institute of Justice Journal http://www.nij.gov/journal/257/hate-crime.html (accessed 2011 . 03-01). In the USA "hate crimes" are also referred to as "bias" crimes, since both hatred and bias underlie the prejudice Harris "Arranging Prejudice: Exploring Hate Crime in PostApartheid South Africa" 2004 http://www.csvr.org.za/docs/racism/arrangingprejudice (accessed 2011-09-01) inherent in these crimes. The Federal Bureau of Investigation (FBI) defines a hate crime as "a criminal offence committed against a person, property or society that is motivated in whole or in part by the offender's bias against a race, religion, disability, sexual orientation or ethnicity/national origin; and Website of the FBI http://www.fbi.gov (accessed 2011-03-12).

10 Mufweba "Corrective Rape Makes You an African Woman" 2003 The Star http://www.iol.co.za (accessed 2011-03-09).

11 Mkhize et al The Country We Want to Live in: Hate Crimes and Homophobia in the Lives of Black Lesbian South Africans 5.

$12 \mathrm{Eg}$, the Convention on the Elimination of all forms of Discrimination against Women (CEDAW), which was ratified by the Republic of South Africa in 1994. See also s 9, 10 and 12 of the Constitution of the Republic of South Africa Act, 1996. 


\section{The course and incidence of orientation-biased attacks on black lesbian South Africans}

\section{Research results revealed three South African studies that have dealt directly or indirectly with crimes against black lesbians ${ }^{13}$}

One of the first academic articles to deal with the problem of violence against black lesbian women in South Africa, albeit not specifically, refers to a study on homophobic violence conducted by the Lesbian and Gay Equality Project in 2001 and $2002{ }^{14}$ The study included a survey that covered the Johannesburg central business district and suburbs. It also included interviews with black lesbians in two townships. ${ }^{15} \mathrm{~A}$ total of 42 respondents, including lesbian women, homosexual men and transgendered persons of all races, participated in the study. 31 of the respondents were lesbian women. According to the findings of this study, $92 \%$ of the lesbian women had been verbally abused, $5.5 \%$ had been the victims of robbery, $91 \%$ had been assaulted and $32 \%$ had been raped at some point.

While shedding some light on violence against lesbian women in Johannesburg and surrounding areas, it is not clear from the findings of this survey precisely how many black lesbian women were assaulted or subjected to verbal abuse, nor how many were the victims of rape or the apparent motive for their rapes. More revealing in this study, however, were the results of the interviews conducted with black lesbian women in two townships. In Kwa-Thema Township, east of Johannesburg, black lesbian respondents attested to being victimized by gangs of men and of being raped. One victim recounted her tale of being gang-raped by twelve men. ${ }^{16}$ Similarly, in interviews conducted in Soweto, it emerged that black lesbians were subjected to "high levels of threats of rape, to attempted rape and to rape".

13 Shortly after the conclusion of this two-part article, Human Rights Watch released the findings of their study dealing inter alia with crimes against black lesbian women in South Africa. The Human Rights Watch study was conducted between 2009 and 2010 and the results released in December 2011. While the findings in this study have not been included in the present submission, they ostensibly confirm most of the findings of abuse of black lesbian women in the prior research studies, ie, verbal, physical and sexual abuse.

14 Reid and Dirsuweit "Understanding Systemic Violence: Homophobic Attacks in Johannesburg and Surrounds" 2002 31(3) Urban Forum 99107.

15 Under British Colonial rule in South Africa "location" designated "a portion of land set apart by a municipality somewhere on the outskirts of the town, upon which natives are allowed to ... reside" Pettman A Glossary of South African Colloquial Words and Phrases and of Place and Other Names (1913) 298. "Natives" at the time referred to black people. The colonialgovernment policy was to "preserve the natives distinct from the whites" Pettman A Glossary of South African Colloquial Words and Phrases and of Place and Other Names 299. Under the post-colonial policy of apartheid, this residential segregation continued and many South African persons of colour (ie, blacks, coloureds and Indians) were forcibly removed from inner city areas to their respective locations, which came to be known as "townships". Most townships today can be found on the outskirts of South African cities and towns.

16 Reid and Dirsuweit 2002 31(3) Urban Forum 113.

17 Reid and Dirsuweit 2002 31(3) Urban Forum 116. 
In 2002 The Forum for the Empowerment of Women, with the assistance of Behind the Mask, undertook research dealing with the crisis of rape, assault and harassment of black lesbians living in Alexandra Township, north of Johannesburg. ${ }^{18}$ This qualitative and anecdotal study was based on interviews conducted with black lesbian respondents. According to Mkhize, this was the first time that the issue of violence against black lesbian women was specifically addressed in South Africa. ${ }^{19}$ The Forum for the Empowerment of Women's initiatives led to the establishment of an advocacy and support group called The Rose has Thorns. The aim of the group was to "mobilise black lesbian women into a force for change" and "to confront the realities of rape, sex, violence and other violations" based on sexual orientation. ${ }^{20}$ The group generated a petition that urged the government to take action against hate crimes perpetrated against black lesbians. ${ }^{21}$

In one of the first media articles regarding the Rose has Thorns campaign in 2003 , it was reported that " 33 black lesbians have come forward with their stories of rape, assault, sexual assault and verbal abuse". ${ }^{22}$ The victims, ranging in age from 16 to 35 , were predominantly masculine or "butch"-23 lesbian women, living openly as lesbians in townships such as Sharpeville, Tembisa, White City, Kagiso, Pimville, Alexandra and Kwa-Thema in the greater Johannesburg area. ${ }^{24}$ Muholi also found that of the 47 black lesbians interviewed, 20 had been raped, 17 assaulted, 8 verbally abused and 2 abducted. The majority of the victims were under the age of $25{ }^{25}$

A 2002/2003 quantitative study on the levels of empowerment of lesbian women and homosexual men between the ages of 16 and 40 years conducted in metropolitan Gauteng by the Pretoria-based non-governmental organization OUT ${ }^{26}$ included 487 participants. $45 \%$ of the participants were lesbian women, of whom 160 (74\%) were black and 56 (26\%) white. The study examined, inter alia, victimization experienced by the respondents. The results of this study revealed that more white than black lesbians were

18 Mkhize et al The Country We Want to Live in: Hate Crimes and Homophobia in the Lives of Black Lesbian South Africans 29.

19 Ibid.

20 From the website of the Forum for the Empowerment of Women (FEW) http://www. few.org.za (accessed 2011-03-11).

21 Amusa "This Rose has Thorns" 2005 Mail \& Guardian http://www.mg.co.za (accessed 201103-17).

22 Mufweba "Corrective Rape Makes You an African Woman" 2003 The Star http://www.iol.co.za (accessed 2011-03-09).

23 The term "butch" is not used here in a derogatory sense, but rather to describe a person who has traditionally masculine traits, behaviour, style and/or self-perception. The term "butch" (as opposed to "femme") is used loosely in the lesbian, gay, bisexual and transgender (LGBT) milieu in order to describe a woman who is more masculine. Note that not all lesbians subscribe to these role identification labels; however, the research to which the authors refer seems to indicate that "butch" lesbian women are frequent targets for biasmotive attacks. A complete discussion of the description of a lesbian woman as "butch" or "femme" is beyond the scope of this submission.

24 Mufweba "Corrective Rape Makes You an African Woman" 2003 The Star http://www.iol.co.za (accessed 2011-03-09).

25 Muholi 200461 Agenda 118.

26 Wells and Polders "Levels of Empowerment Amongst Lesbian, Gay, Bisexual and Transgendered People in Gauteng, South Africa" 2004 Out LGBT Wellbeing \& the UNISA Centre for Applied Psychology 2. 
subjected to verbal abuse $(52.7 \%$ of whites as compared with $47.7 \%$ of blacks). More black lesbians, however, were the victims of rape and sexual abuse than whites $(64.5 \%$ of blacks as compared with $50.9 \%$ of whites). $53 \%$ of the black lesbian respondents experienced physical abuse, as opposed to $43.6 \%$ of white lesbians.

\section{Commentary on the three studies}

As a point of criticism, all three studies focused on the province of Gauteng, and were based on the responses of a limited number of participants. The limited scope of the studies shows correlation as opposed to causation. The province of Gauteng may, essentially, present a unique socio-economic group. Without criticizing the methodology of the researchers, we, the authors, approach the results, in the absence of further research specific to black lesbian South Africans, from a potential correlation perspective.

Verbal abuse was the most common form of abuse experienced by lesbian woman of all races in all three studies. In the Equality Project study most of the lesbian women (over $90 \%$ ) had been verbally abused. In OUT's 2002/2003 study more white lesbians were subjected to verbal abuse than black lesbian women. No clear figures or percentages for verbal abuse are provided in the Forum for the Empowerment of Women's study, although it was reported to the interviewers. Muholi, for example, found that of the 47 lesbian women she had interviewed, 8 had been verbally abused. It is not apparent precisely which forms of conduct constituted verbal abuse in the three studies. Nel and Judge, who consider hate speech as a form of verbal abuse, include "harassment, slurring and name calling" among the examples of verbal abuse of homosexual persons. ${ }^{27}$ Further examples of verbal abuse in media discourse are "teasing and comments" orientation and referring to lesbian women as "diseased". ${ }^{29}$ Muholi also refers to the example of calling a lesbian woman a "pervert". ${ }^{30}$ In the OUT study, Wells and Polders found that verbal abuse is the "least reported" form of anti-gay and lesbian victimization. ${ }^{31}$ They further opine that it is probably because verbal abuse causes no "physical injury" that it is "tolerated by society".

In all three studies physical abuse and assault are the second most common offences committed against lesbian women. In the Equality Project study, $91 \%$ of lesbians had been the victims of assault. In the OUT study, $43.6 \%$ of white and $53 \%$ of black lesbians had experienced physical abuse.

27 Nel and Judge "Exploring Homophobic Victimisation in Gauteng, South Africa: Issues, Impacts \& Responses" 2008 21(3) Acta Criminologica 1922.

28 Stewart "Discrimination mars Freedom Day Celebrations" 2005 The Star http://www. iol.co.za/news/politics/discrimination-mars-freedom-day-celebrations (accessed 2011-0520).

29 Edward Malumela, a resident of Vosloorus, quoted in Taylor "Lesbians in South Africa continue to Suffer 'Corrective Rape' and Murder" 2011 VOANews http://www.voanews.com/ english/news/africa/southern/lesbians-in-south-africa-con (accessed 2011-05-10).

30 Muholi "Mapping Our Histories: A Visual History of Black Lesbians in Post Apartheid South Africa" 2010 http://www.zanelemuholi.com (accessed 2011-15-03) 20.

31 Wells and Polders 200667 Agenda 25.

32 Wells and Polders 200667 Agenda 23. 
While assault is mentioned in the Forum for the Empowerment of Women's study, exact percentages are not provided. 17 of Muholi's 47 interviewees had been assaulted. None of the studies, however, provide details as to which forms of conduct qualified as assault or physical abuse. It should be noted that assault in South African law is a common-law crime that entails "the application of force to the body of another" and could imply either common assault or the more serious assault with intent to do grievous bodily harm. ${ }^{33}$

The third most common form of abuse experienced was sexual abuse and rape. In the Equality Project study, 32\% of lesbians of all races reported sexual abuse and rape. It is unclear, however, precisely which forms of conduct constituted sexual abuse in the study. Black lesbian respondents also reported rape, attempted rape and threats of rape to the interviewers in this study. In the OUT study, $64.5 \%$ of black lesbians as opposed to $50.9 \%$ of white lesbians reported rape. Black lesbians were ostensibly more susceptible to rape than white lesbians were. While black lesbians complained of rape in The Forum for the Empowerment of Women's study, it is not clear how many were subjected to rape. Of the 47 respondents interviewed by Muholi, 20 had been raped. It should be borne in mind that while a number of forms of conduct could constitute the crime of rape in present South African law, in terms of the Criminal Law (Sexual Offences and Related Matters) Amendment $\mathrm{Act}^{34}$, at the time that the three studies were conducted the law relating to rape was based on the limited commonlaw definition. The common-law definition emphasized non-consensual, vaginal intercourse between a man and a woman. It can therefore be assumed that the lesbian women who were raped were subjected to nonconsensual, vaginal intercourse perpetrated by men. What is also apparent from the Forum for the Empowerment of Women's study is that overtly masculine black lesbians were frequent targets of rape. One inference that can be drawn is that the rape attacks on black lesbian women were motivated not only on the basis of their sexual preference, but also on the basis of the manner in which they presented themselves, possibly through their attire, behaviour and identification with a masculine persona. This seems to resonate with Muholi's statement that most of the rape survivors were raped "explicitly because of their sexual orientation and gender identity" ${ }^{35}$ We concede that causation is not proved, but submit that the correlation is sufficient to warrant further study.

Other crimes mentioned in the studies included two cases of abduction reported in the Forum for the Empowerment of Women's study and robbery, reported by $5.5 \%$ of victims participating in the Equality Project study. ${ }^{36}$

While all three studies point to the victimization of lesbian women, some writers caution that crimes against sexual minorities are not always

\footnotetext{
Snyman Criminal Law (2008) 456.

32 of 2007.

Muholi 200461 Agenda 118.

36 The South African legal definition of the crime of abduction refers to the unlawful removal of a minor from the control of her parents with the express intention of marrying or engaging in sexual intercourse with the minor (Snyman Criminal Law 403). Robbery is the appropriation of property by the use of violence or the threat of violence (Snyman Criminal Law 517).
} 
motivated by hatred or bias based on the sexual orientation or gender identity of the victim. In other words, it is not necessarily because the victim falls into a particular social group that she is attacked on the basis of her "symbolic status" within this group. Lesbian women could also be the victims of crime because of their "actuarial status", according to which the perpetrators make assumptions of "central tendencies" associated with a particular group. ${ }^{38}$ According to this view, therefore, lesbian women could be targeted as victims of crime because the perpetrators assume that all women are easier targets and less likely to retaliate when attacked. It is our submission, however, that this view may serve as a plausible argument in the case of a lesbian woman who is the victim of robbery. However, in the preceding research, the victimization of lesbian women by gangs of men, the verbal abuse, the threats of rape and the fact that the Forum for the Empowerment of Women's study revealed that the victims were raped because of their sexual orientation and gender identity all indicate that it was not the victims' "actuarial status" but their "symbolic status" as black, overtly masculine, lesbian women which motivated the crimes.

\section{Corrective/Curative rape}

The Forum for the Empowerment of Women's Rose has Thorns project further revealed that the black lesbian survivors of rape were subjected to a particular form of rape referred to initially as "curative rape"39 but more commonly as "corrective rape" in South African parlance and in media discourse. ${ }^{40}$ While research has shown that most rapes are acts of power in which the rapist objectifies and dehumanizes his victim ${ }^{41}$ and that rape is an act of "humiliation and punishment", ${ }^{2}$ "corrective rape" can be distinguished from other rapes in that there is an additional motive, which is to "cure",43 or "correct" ${ }^{\text {"4 }}$ a lesbian woman's sexual orientation. Kruger similarly opines that "corrective rape" is "motivated by the idea that lesbian women are attempting to be men and is designed to 'prove' that they are women". 45

37 Berk "Thinking About Hate Motivated Crime" 19905 Journal of Interpersonal Violence 334 338.

38 Berk 19905 Journal of Interpersonal Violence 339.

39 Muholi 200461 Agenda 118.

40 According to most of the anecdotal reports, black lesbian women in South Africa are almost always the victims of "corrective rape". There is, however, some suggestion that a few coloured lesbians have also been subjected to "corrective rape", but this is not immediately evident from most media reports. Gontek Sexual Violence Against Lesbian Women in South Africa (2007) 42, also refers to the 2004 case of a young white lesbian, Riana, who was raped by several policemen because she was perceived as trying "to be a man".

41 Vogelman and Lewis "Gang Rape and the Culture of Violence in South Africa" 1993 http://www.csvr.org.za/wits/papers/papl.svl.htm (accessed 2011-05-10).

42 Vetten, Jewkes, Sigsworth, Christofides, Loots and Dunseith "Tracking Justice: The Attrition of Rape Cases Through the Criminal Justice System in Gauteng" 2008 Tshwaranang Legal Advocacy Centre, the South African Medical and Dental Council \& the Centre for the Study of Violence \& Reconciliation 42.

43 Kelly "Raped and Killed for Being a Lesbian" 2009 The Guardian http://www.guardian.co.za (accessed 2011-03-09).

44 Thorpe "Nothing to Correct" 2011 Mail \& Guardian http://www.Thoughtleader.co.za (accessed 2011-03-07).

45 Kruger quoted in Gontek Sexual Violence Against Lesbian Women in South Africa 42. 
Some activists, such as Bernadette Muthien of the non-governmental organization Engender, insist on using the term "curative rape" since it is felt that the term "curative" is more powerful and refers to "rape as a cure" 46 for a lesbian woman's sexual orientation. However, the verbal abuse before and during the rapes, recalled in the testimonies of some of the survivors, reveals that the perpetrators "wanted to teach them a lesson ... [and] . show them how to be real women" and correct their sexual orientation. ${ }^{4}$ Hence, the adjective "corrective" was coined in South African township parlance, in media discourse and in anecdotal reports to describe this form of rape.

It should be noted that "corrective rape" is not a uniquely South African phenomenon. According to Muthien it is "a global phenomenon ... and it is $\ldots$ used as a tool to control people's sexuality, women in particular". ${ }^{48}$ This view is also echoed in research undertaken by Martin et al, who assert that human-rights violations of people based on their sexual orientation (which include "corrective rape") are of a "global nature". ${ }^{49}$ Mieses cites examples of the "corrective rape" of a young lesbian woman in Zimbabwe who was raped with the complicity of her family members, of a lesbian factory worker in Thailand who was raped by co-workers because she "was wasting her beauty as a lesbian" and of a lesbian woman who was raped in Georgia, USA because, the rapist had "vowed to teach her a lesson".

\section{Other reports and anecdotal evidence}

To date, anecdotal evidence on the sexual abuse and violation of black lesbian women in South Africa is overwhelming. In 2009, Action Aid, a nongovernmental organization, interviewed 15 survivors of "corrective rape". The report affirms that "black-lesbians, who lack sufficient support systems and are already disadvantaged by cultural, economic and social discrimination .... are particularly at risk". ${ }^{51}$ In fact, the discrimination referred to in the Action Aid report is also directed at younger, school-going lesbians. This confirms the findings of Muholi, who found in 2004 that young black lesbian girls were forced to leave school and were unable to complete their studies since they did not adhere to "gender-specific dress codes" and because they were overt about their sexual orientation. ${ }^{52}$ This culture of

46 Muthien quoted in Bucher "Law Failing Lesbians on 'Corrective Rape'" 2009 IPS News http://ipsnews.net/news.asp (accessed 2011-03-16).

47 Martin, Kelly, Turquat and Ross "Hate Crimes: The Rise of Corrective Rape in South Africa" 2009 http://www.actionaid.org.uk/doc_lib/correctiveraperep_final.pdf (accessed 2011-12-13) 12.

48 Muthien quoted in Bucher "Law Failing Lesbians on 'Corrective Rape'" 2009 IPS News http://ipsnews.net/news.asp (accessed 2011-03-16).

49 Martin et al "Hate Crimes: The Rise of Corrective Rape in South Africa" 2009 http://www.actionaid.org.uk/doc_lib/correctiveraperep_final.pdf (accessed 2011-12-13) 6.

50 Mieses "Gender Inequality and Corrective Rape of Women Who have Sex with Women" 2009 http://www.thebody.com/contents/arts.56244.html (accessed 2011-05-04).

51 Martin et al "Hate Crimes: The Rise of Corrective Rape in South Africa" 2009 http://www.actionaid.org.uk/doc_lib/correctiveraperep_final.pdf (accessed 2011-12-13) 8 .

52 Muholi 200461 Agenda 123. The term "overt" in this context is used to indicate a person who is open about and does not attempt to conceal his/her sexual orientation. "Overt" is not used in the context of indicating a particular stance or agenda. 
intolerance towards black lesbian schoolgirls is confirmed once again in a 2008 study conducted by the South African Human Rights Commission. In the report, it is noted that there is a "growing phenomenon of 'corrective rape' in schools across the country with young boys believing that lesbian girls needed to be raped in order to "correct' their sexual orientation".

The incidents referred to above are based on the accounts of lesbian survivors of rape and violence in surveys referred to in academic research and from anecdotal reports. These incidents represent only a fraction of the cases of rape and violence perpetrated against black lesbian women in the recent past. The actual number of cases is "probably much higher". ${ }^{54}$ The Triangle Project, one of the largest gay- and lesbian-rights organizations in South Africa, reported that it was dealing with " 10 new cases of "corrective rape' a week in Cape Town alone". ${ }^{55}$

At the time of writing, further reports were being made concerning a 13year-old openly lesbian girl in Atteridgeville, Pretoria who was allegedly raped in an attempt to correct her sexual orientation. ${ }^{56}$

\section{Rationale for the non-reporting of "corrective rape"}

Based on the aforementioned anecdotal and media reports, a number of cases of "corrective rape" are not reported and are consequently never subjected to scrutiny.

In exploring the reasons why corrective-rape survivors choose to remain silent and refrain from formal complaint, Muholi cites the "emotional trauma" of reliving the incident, the "fear of exposure" to family and friends ${ }^{57}$ and the "humiliation" of secondary victimization by service providers as contributory factors. ${ }^{58}$ Similar findings were made in the Action Aid study, where victims said that they did not report the incident because they "feared exposing their sexual orientation to the police". ${ }^{59}$ Wells and Polders also found that an overwhelming majority of black lesbian (and gay) respondents did not report crimes to the police since they felt that they would "not be taken seriously" and that "the police would not understand". 60 In a 2009 report in The Guardian, a British newspaper, one lesbian-rape survivor stated, "When we try and report these crimes, nothing happens and then you see the boys who

53 Anonymous "Report of the Public Hearing on School-Based Violence" 2008 South African Human Rights Commission http://edulibpretoria.files.wordpress.com/2008/03/sbvreporting recomm.pdf (accessed 2011-03-20) 9.

54 Harrison "South African Gangs use Rape to Cure Lesbians" 2009 http://www.reuters. com/article (accessed 2011-03-09).

55 Kelly "Raped and Killed for Being a Lesbian" 2009 The Guardian http://www.guardian.co.za (accessed 2011-03-09); and Caird "Horror and Hope" 2010 Mail \& Guardian http://mg.co.za/ article/2010-10-05-horror-and-hope (accessed 2011-03-07).

56 Anonymous "13-year-old Lesbian Raped" 2011 http://www.iol.co.za/news/crime-courts/13year-old-lesbian-raped-1.1065547? showComments=true (accessed 2011-08-03).

57 This reason for the non-reporting of "corrective rape" seems to contradict the fact that many of the lesbian victims are overt about their sexuality.

58 Muholi 200461 Agenda 118.

59 Martin et al "Hate Crimes: The Rise of Corrective Rape in South Africa" 2009 http://www.actionaid.org.uk/doc_lib/correctiveraperep_final.pdf (accessed 2011-12-13) 13.

60 Wells and Polders 200667 Agenda 26. 
raped you walking free on the street". ${ }^{61}$ Since reporting a crime to the police is a victim's first point of access to the criminal-justice system, the nonreporting of "corrective rape" is a serious problem, since "a woman's evidence is the prosecution's main weapon in the trial ... it is crucial to secure a conviction" ${ }^{62}$ According to Gontek, public services in South Africa (of which the police form an integral part) are based on a "heterosexual premise" and thus appear "discriminatory" to lesbian women. ${ }^{63}$ Gontek refers to the findings of Kruger, who stated that "lesbian women experience difficulty in accessing appropriate services when they have been raped [and] may fail to report the rape or attempt to do so and be confronted with homophobic service providers". ${ }^{64}$ These findings resonate with the words of Thso Gcakfi, a resident of Khayelitsha township near Cape Town: "township police often laughed (at) or belittled lesbians ... when they reported rapes". ${ }^{55}$ While most of these findings relate to the non-reporting of "corrective-rape" cases they seem to correlate with the findings of a study on rape conducted in Gauteng. According to this study, "rape is extensively under-reported in South Africa ... [and] ... the vast majority of rape cases never come to the attention of the criminal-justice system". 66 However, the study does not provide reasons for the under-reporting of rape in South Africa.

Since most cases of "corrective rape" are not reported in South Africa, accurate statistics are difficult to access. The rape of black lesbians in South Africa is thus impossible to quantify. It is also challenging to study since it is not possible to determine whether this phenomenon occurs in all black townships of South Africa or whether black lesbians in rural areas also experience this form of gender-based violence.

\section{The perpetrators}

In all the cases reported in the studies the perpetrators of "corrective rape" were men, who either committed the act of rape alone or as members of a group. None of the studies, however, provided any indication of the race of the perpetrators. One hint at the race of the perpetrators is provided in Muholi's statement: "Why ... does heterosexual black masculinity appear to be invested in raping black lesbian women?"67 It can therefore be assumed that in the Forum for the Empowerment of Women study and in cases of "corrective rape" in black townships, the perpetrators were heterosexual, black men. In many cases the perpetrators of the attacks were known to the victims as family members, neighbours, friends, members of the community

61 Kelly "Raped and Killed for Being a Lesbian" 2009 The Guardian http://www.guardian.co.za (accessed 2011-03-09).

62 Orford "Violence Against Women is Symptom of a Dread Disease" 2011 TimesLive http://www.timeslive.co.za/opinion/commentary (accessed 2011-08-14).

63 Gontek Sexual Violence Against Lesbian Women in South Africa 49.

64 Kruger quoted in Gontek Sexual Violence Against Lesbian Women in South Africa 49.

65 Quoted in Tham "Not Just Another Murder" 2006 Mail \& Guardian http://www.mg.co.za/ article/2006-02-26-not-just-another-murder (accessed 2011-03-24).

66 Vetten et al "Tracking Justice: The Attrition of Rape Cases Through the Criminal Justice System in Gauteng" 2008 Tshwaranang Legal Advocacy Centre, the South African Medical and Dental Council \& the Centre for the Study of Violence \& Reconciliation 16.

67 Muholi 200461 Agenda 122. 
and gang-members. ${ }^{68}$ Research has suggested the complicity of some mothers of black lesbians who take the initiative of "organizing [the] rape" of their lesbian daughters in the hope that they would fall pregnant and not concentrate on their sexual orientation. ${ }^{69}$ The rapes are then often perpetrated by the woman's cousins. ${ }^{70}$ According to one "corrective-rape" survivor, "I was raped because I was a butch child ... I was thirteen years old the first time it happened ... my mother walked into the room soon after it happened and said to me, this is what happens to girls like you"." These occurrences of "corrective rape" within the family resonate with the findings of Vetten, who in her study established that some children are vulnerable to rape "by family members and those that they know". ${ }^{72}$ Gontek similarly opines that in the lives of black lesbian women "the family ... constitutes a source of danger that is not to be underestimated". ${ }^{73}$

In one interview conducted with an ex-rapist it was revealed that the rapist made a conscious decision to control lesbian women through rape and that the rape attack was planned with fellow members of a gang. ${ }^{74}$ The perpetrators of the rape use a twisted logic or rationale to justify their behaviour by claiming that "they are acting in the lesbian's interest by teaching her to behave like a woman"75 or that they wanted to "turn her into a real African woman" 76 or that they wanted "to turn her straight".

\section{Consequences of "corrective rape"}

Concerning the effects of the "corrective rape" attacks on black lesbian women, Reddy notes that a number of survivors are left pregnant or infected with the human immunodeficiency virus. ${ }^{78}$ Luleka Makiwane was one such black lesbian woman who contracted the human immunodeficiency virus after a "corrective rape" attack and later succumbed to Aids. ${ }^{79}$ Muholi also refers to the case of Busi Sigasa, a lesbian activist who was raped and

68 Mufweba "Corrective Rape Makes You an African Woman" 2003 The Star http://www.iol.co.za (accessed 2011-03-09).

69 Betterridge quoted in Gontek Sexual Violence Against Lesbian Women in South Africa 45.

70 Hewat and Arndt quoted in Gontek Sexual Violence Against Lesbian Women in South Africa 45.

71 Kekeletso Khena quoted in Mufweba "Corrective Rape Makes You an African Woman" 2003 The Star http://www.iol.co.za (accessed 2011-03-09).

72 Vetten et al "Tracking Justice: The Attrition of Rape Cases Through the Criminal Justice System in Gauteng" 2008 Tshwaranang Legal Advocacy Centre, the South African Medical and Dental Council \& the Centre for the Study of Violence \& Reconciliation 42.

73 Gontek Sexual Violence Against Lesbian Women in South Africa 45.

74 Muholi 200461 Agenda 121.

75 Reddy, Potgieter and Mkhize "Cloud Over the Rainbow Nation: Corrective Rape and Other Hate Crimes Against Black Lesbians" 2007 5(1) HSRC Review 10.

76 Mufweba "Corrective Rape Makes You an African Woman" 2003 The Star http://www.iol.co.za (accessed 2011-03-09).

77 Canning "In South Africa, Finally Some Action on "Corrective Rape" 2011 LGBT Asylum News http://madikazemi.blogspot.com/2011/01/in-south-africa-finally-some-action-on.html (accessed 2011-05-04). It should be noted that the word 'straight' is used in the lesbian, gay, bisexual and transgender (LGBT) milieu to denote a heterosexual person.

78 Reddy et al 2007 5(1) HSRC Review 10.

79 Bucher "Law Failing Lesbians on 'Corrective Rape"” 2009 IPSNews http://ipsnews. net/news.asp (accessed 2011-03-16). 
contracted the human immunodeficiency virus. She also succumbed to Aids in $2007 .^{80}$ "Corrective rape" is said to be one of the "main reasons for the HIV infection of lesbian women"; 81 however, no accurate data exists in South Africa relating to the extent of the human immunodeficiency virus infection among lesbian women. ${ }^{82}$ It goes without saying that the survivors also risk contracting other sexually transmitted diseases. Moreover, "corrective rape" has psychological effects. According to one study on the health effects of rape, it was found that one third of South African women who are raped develop post-traumatic stress disorder, which could, if untreated, in the long term lead to depression, suicide and substance abuse. ${ }^{83}$ Corrective-rape survivors are also so traumatized that they live in constant fear, which, according to Nel and Judge, "can have a chilling effect on the ways ... [they] ... present themselves in public, often encouraging them to play down or "closet" their sexual orientation or gender non-conformity" ${ }^{84}$ As one rape survivor stated: "You are always scared and your life always feels restricted ... as lesbians we need to be very aware that it is a fact of life that we are in danger" ${ }^{85}$ While we do not suggest that "corrective rape" leaves deeper scars than the rape of heterosexual women or the rape of men, it is our submission that the compounding of the orientation motive in "corrective rape" deepens the sense of shame.

\section{$3 \quad$ Murder committed with an orientation motive}

Most of the evidence of violence against black lesbian South Africans is based on the personal narratives of survivors and has focused inter alia on verbal abuse, harassment, assault and "corrective rape". There is, however, compelling evidence that a number of black lesbian women have been murdered in consequence of their openly lesbian status. According to Ndumie Funda, who runs an initiative called Luleki Sizwe ${ }^{86}$ to support lesbian women in Gugulethu near Cape Town, "women are getting killed in the Western Cape ... and ... young lesbian women aged between 16 and 25 are most vulnerable". ${ }^{87}$ Some sources allege that over thirty such murders have been perpetrated in South Africa. ${ }^{88}$ However, exact figures are difficult to ascertain. Mkhize et al have documented more than ten cases involving

80 Muholi "Mapping Our Histories: A Visual History of Black Lesbians in Post Apartheid South Africa" 2010 http://www.zanelemuholi.com (accessed 2011-15-03) 123.

81 Kruger quoted in Gontek Sexual Violence Against Lesbian Women in South Africa 48.

82 Gontek Sexual Violence Against Lesbian Women in South Africa 49.

83 Jewkes, Abrahams, Matthews, Seedat, van Niekerk, Suffla and Ratele "Preventing Rape and Violence in South Africa: Call for Leadership in a New Agenda for South Africa" 2009 http://www.mrc.ac.za/gender (accessed 2011-03-25) 1.

84 Nel and Judge 2008 21(3) Acta Criminologica 27.

85 Phumla, a victim quoted in Martin et al "Hate Crimes: The Rise of Corrective Rape in South Africa” 2009 http://www.actionaid.org.uk/doc_lib/correctiveraperep_final.pdf (accessed 201112-13) 8.

86 Named after her late fiancée, Nosizwe Nomsa Bizana, who was gang-raped and eventually died of crypto-meningitis, and her friend, Luleka Makiwane, who is referred to earlier in this article.

87 Ndumie Funda quoted in Bucher "Law Failing Lesbians on 'Corrective Rape'” 2009 IPSNewS http://ipsnews.net/news.asp (accessed 2011-03-16).

88 Martin et al "Hate Crimes: The Rise of Corrective Rape in South Africa" 2009. http://www.actionaid.org.uk/doc_lib/correctiveraperep_final.pdf (accessed 2011-12-13) 13. 
the rape and murder of young black lesbian women in several black townships and some urban areas in South Africa between 2006 and $2009 .^{89}$ These cases can most effectively be presented in the following table:

\begin{tabular}{|c|c|c|c|c|}
\hline Name & Age & Date & Place & $\begin{array}{l}\text { Offence(s) } \\
\text { committed by } \\
\text { the } \\
\text { perpetrator }\end{array}$ \\
\hline $\begin{array}{l}\text { Zoliswa } \\
\text { Nkonyana }\end{array}$ & 18 & 4 February 2006 & $\begin{array}{l}\text { Khayelitsha, } \\
\text { Cape Town }\end{array}$ & $\begin{array}{l}\text { Murdered } \\
\text { (stoned, stabbed } \\
\text { and } \\
\text { beaten with a } \\
\text { golf club) }\end{array}$ \\
\hline $\begin{array}{l}\text { Madoe } \\
\text { Mafubedu }\end{array}$ & Unknown & April 2007 & Unknown & $\begin{array}{l}\text { Raped \& } \\
\text { murdered } \\
\text { (stabbed) }\end{array}$ \\
\hline $\begin{array}{l}\text { Sizakele } \\
\text { Sigasa }\end{array}$ & 34 & 7 July 2007 & $\begin{array}{l}\text { Soweto, } \\
\text { Johannesburg }\end{array}$ & $\begin{array}{l}\text { Raped \& } \\
\text { murdered } \\
\text { (tortured) }\end{array}$ \\
\hline $\begin{array}{l}\text { Salome } \\
\text { Massoa }\end{array}$ & 23 & 7 July 2007 & $\begin{array}{l}\text { Soweto, } \\
\text { Johannesburg }\end{array}$ & $\begin{array}{l}\text { Raped \& } \\
\text { murdered } \\
\text { (tortured) }\end{array}$ \\
\hline $\begin{array}{l}\text { Thokozane } \\
\text { Qwabe }\end{array}$ & 23 & 22 July 2007 & $\begin{array}{l}\text { Ezakheni, } \\
\text { Ladysmith }\end{array}$ & $\begin{array}{l}\text { Murdered (by } \\
\text { stoning) }\end{array}$ \\
\hline $\begin{array}{l}\text { Eudy } \\
\text { Simelane }\end{array}$ & 31 & 28 July 2008 & $\begin{array}{l}\text { Kwa-Thema, } \\
\text { near } \\
\text { Johannesburg }\end{array}$ & $\begin{array}{l}\text { Raped \& } \\
\text { murdered }\end{array}$ \\
\hline $\begin{array}{l}\text { Khanyiswa } \\
\text { Hani }\end{array}$ & 25 & 26 May 2008 & $\begin{array}{l}\text { New Brighton, } \\
\text { Port Elizabeth }\end{array}$ & $\begin{array}{l}\text { Murdered } \\
\text { (stabbed) }\end{array}$ \\
\hline $\begin{array}{l}\text { Daisy } \\
\text { Dube }\end{array}$ & Unknown & 2 June 2008 & $\begin{array}{l}\text { Yeoville, } \\
\text { Johannesburg }\end{array}$ & Murdered (shot) \\
\hline $\begin{array}{l}\text { Sibongile } \\
\text { Mphelo }\end{array}$ & 21 & 20 June 2008 & $\begin{array}{l}\text { Strand, Cape } \\
\text { Town }\end{array}$ & $\begin{array}{l}\text { Raped \& } \\
\text { murdered (shot } \\
\& \\
\text { genitally } \\
\text { mutilated) }\end{array}$ \\
\hline $\begin{array}{l}\text { Girly } \\
\text { S'Gelane } \\
\text { Nkosi }\end{array}$ & 37 & 22 June 2009 & $\begin{array}{l}\text { Kwa-Thema, } \\
\text { near } \\
\text { Johannesburg }\end{array}$ & $\begin{array}{l}\text { Murdered } \\
\text { (stabbed) }\end{array}$ \\
\hline
\end{tabular}

From the limited evidence relating to the above cases, it can be ascertained from the names of the victims that they were all black women. All the victims were from urban and suburban areas of South Africa. While not all the victims were raped, it can be assumed that most of the victims who were raped before being murdered were subjected to "corrective rape". The two cases of torture, two of stoning and one of genital mutilation indicate the severity and cruelty of the punishment that the perpetrators intended to inflict on the victims. It also strongly suggests the motivation of bias or hatred in these crimes.

89 Mkhize et al The Country We Want to Live in: Hate Crimes and Homophobia in the Lives of Black Lesbian South Africans 46-47. 
The South African common law does not recognize hate crimes as a separate category of crimes. South African statutory law, however, does contain provisions which criminalize hate speech. ${ }^{90}$ However, the crime of hate speech would not have been the appropriate crime with which to have charged the perpetrators in the aforementioned cases of violence against lesbian women. Therefore the rape and/or murder of a lesbian woman committed with a hate/bias/orientation motive would be legally defined as any other rape or murder. Bucher consequently opines, "the police refuse to investigate on the basis of hate". ${ }^{91}$ It is our submission that the inaction on the part of the police is partly due to this lacuna in South African law.

At the time of writing, the most recent case of murder involving a black lesbian woman was the case of 24-year-old Noxolo Nogwaza, an activist from Kwa-Thema Township. She was stoned, raped and murdered on 24 April 2011. ${ }^{92}$ According to a South African Police Service spokesperson, Tshisikhawe Ndou, there is no "evidence to conclude that the crime was committed against her based on the fact of her sexual orientation ... it is just purely murder and rape that we are investigating at this stage". ${ }^{93}$

\section{Cases appearing before the court}

At the time of writing, only two cases reflected in the table above had been to trial. The first case, in 2006, involved the murder of Zoliswa Nkonyana. The crime was termed a "classic hate crime",94 and as one that pointed to homophobia. ${ }^{95}$ Six of the nine perpetrators were arrested and appeared in court for the first time shortly after the murder. However, two of the accused were released since there was insufficient evidence against them ${ }^{96}$ In 2010, four years after the incident, the case had still not been resolved and four of the perpetrators had escaped from the Khayelitsha jail, allegedly with the help of a police official. ${ }^{97}$ The rape and murder trial of Zoliswa Nkonyana was postponed at least thirty times leading to accusations that the "system was failing Nkonyana because she was a black lesbian from a poor family". ${ }^{98}$

90 In terms of section 10 of the Promotion of Equality and Prevention of Unfair Discrimination Act 4 of 2000.

91 Bucher "Law Failing Lesbians on 'Corrective Rape"” 2009 IPSNews http://ipsnews. net/news.asp (accessed 2011-03-16).

92 Jadoo "Task Team Set Up to Tackle Homophobic Attacks" 2011 Mail \& Guardian http://mg. co.za/article/2011-05-04-task-team-set-up-to-tackle-homophobic-attacks (accessed 201105-05).

93 Anonymous "Epidemic of Hate Crimes Against Gays" 2011 http://www.news24.com/ SouthAfrica/News/Epidemic-of-hate-crimes-against-gays (accessed 2011-05-05).

94 Tham "Not Just Another Murder" 2006 Mail \& Guardian http://www.mg.co.za/article/2006-0226-not-just-another-murder (accessed 2011-03-24).

95 As per Cape Town's Triangle Project quoted in Anonymous "Murder of Lesbian Sparks Homophobia Concerns" 2006 Mail \& Guardian http://www.mg.co.za/article/2006-02-21 murder-of-lesbian-sparks-homophobic-concerns (accessed 2011-24-03).

96 Budaza "Lesbian Murder Accused Released" 2011 http://www.iol.co.za/capetimes/lesbianmurder-accused-released (accessed 2011-10-11).

97 Caird "Horror and Hope" 2010 Mail \& Guardian http://mg.co.za/article/2010-10-05-horrorand-hope (accessed 2011-03-07).

98 Member of the Treatment Action Campaign (TAC), Nomfusi Nomnqa quoted in Anonymous "Courts Snub Blacks" 2011 Sowetan Live http://www.sowetanlive.co.za/news/2011/03/ 11courts-snub-blacks (accessed 2011-06-15). 
The case was eventually heard in September 2011. Four of the remaining seven accused were eventually found guilty of Zoliswa's murder on 7 October 2011. ${ }^{99}$ Owing to insufficient evidence three of the accused could not be linked to the murder. ${ }^{100}$ According to Marlow Valentine of the Triangle Project, "it was cause for concern that not all nine of the men had been found guilty" as a result of "poor evidence collected by the police". ${ }^{10}$

The second case, in 2008, involved the rape and murder of Eudy Simelane, a soccer player on the national women's soccer team, Banyana Banyana. Simelane was described as a vociferous equality-rights campaigner and one of the first women to live openly as a lesbian in KwaThema. ${ }^{102}$ The first accused in this case, Thato Mpithi, pleaded guilty to murder, robbery and attempted rape. ${ }^{103}$ He was sentenced to 32 years' imprisonment in 2009. ${ }^{104}$ However, the victim's sexuality was "ruled out in the first sentencing as a motive in her killing". ${ }^{105}$ The second accused, Themba Mvubu, an unemployed 24-year-old man, was convicted of murder, robbery and of being an accessory to rape in 2009. He was sentenced to life imprisonment. ${ }^{106}$ The presiding judge, Ratha Mokgoathleng, while describing the crime as "callous and inhumane", nevertheless refused to accept that Simelane's sexual orientation was the primary motivation for her murder. ${ }^{10}$

\section{The present position}

At the time of writing, civil-society organizations are continuing their activist work with black lesbian women. The establishment of the 07-07-07 Campaign by a joint working group of a number of civil-society organizations is one such example. ${ }^{108}$ 07-07-07 is a reference to the day, month and year in which Sizakele Sigasa and Salome Massoa, two of the victims referred to in the earlier table, were raped and murdered. The campaign aims to highlight the violence perpetrated against lesbian women, record incidents of hate crime, maintain a presence at the cases that are eventually brought to trial, and provide a co-ordinated response to the problem.

Another noteworthy development is the online petition initiated in late 2010 on Change.org by Luleki Sizwe. The aim of the petition is to draw

99 Anonymous "Four Guilty of Lesbian's Murder" 2011 http://www.iol.co.za/news/crimecourts/four-guilty-of-lesbians-murder-1.1152918 (accessed 2011-10-11).

100 Ibid.

101 Quoted in Jones "Activists Celebrate Conviction" 2011 http://www.iol.co.za/capetimes/ activists-celebrate-conviction-1.1153770 (accessed 2011-10-11)

102 Kelly "Raped and Killed for Being a Lesbian" 2009 The Guardian http://www.guardian.co.za (accessed 2011-03-9).

103 Anonymous "Corrective Rape Thought to be Motive behind Gang Rape and Murder of Eudy Simelane" 2009 http://www.buzzle.com/articles/31045.html (accessed 2011-03-09).

104 Ibid.

105 Anonymous "Simelane's Killer Jailed for Life" 2009 TimesLIVE http://www.timeslive.co.za/ news/article/26622.ece (accessed 2011-03-29).

106 Anonymous "Corrective Rape Thought to be Motive behind Gang Rape and Murder of Eudy Simelane" 2009 http://www.buzzle.com/articles/31045.html (accessed 2011-03-09).

107 Ibid.

108 These organizations include a number of civil society organizations, including Action Aid, People Opposing Women Abuse and the Treatment Action Campaign. 
international attention to the horror of "corrective rape" and to persuade the South African Ministry of Justice to declare "corrective rape" a hate crime. ${ }^{109}$ Following the killing of Noxolo Nogwaza in April 2011, activists held a protest march against "corrective rape" and gender-based violence in Kwa-Thema township.

To date, the most significant development has been the announcement in May 2011 by the South African Ministry of Justice and Constitutional Development that a national task team would be established to address the issue of hate crimes against lesbian women and homosexual men. The proposed task team will include representatives from the judiciary, police service, and social development and from the lesbian, gay, bisexual, transgender and intersex community. The task team will be responsible for the development of a "legislative intervention plan, a public awareness strategy and LGBTI sensitive shelters". ${ }^{111}$ It is the author's submission that it is not merely coincidental that the proposed national task team was announced shortly after the Change.org petition had attracted local and international attention and had garnered over 170000 signatures. ${ }^{112}$

The awareness at national-government level of the problem of genderbased violence against lesbian women seems to be filtering through to other government departments. On 21 June 2011 the national Minister for Women, Children and People with Disabilities, Ms Lulu Xingwana, stated during a budget speech in South Africa's national parliament that "urgent action is needed to stop the scourge of violence against lesbians ... [and that] ... the right to sexual orientation as stipulated in our Constitution is ... being violated through the so-called 'corrective rape' of lesbian women". ${ }^{113}$

\section{Orientation-based violence - a limited causal explanation}

As alluded to earlier, ${ }^{114}$ since 2006 gender-based violence against lesbian women in South Africa has been recognized as falling under the broader concern of gender-based violence against women. A positive consequence of this inclusive approach is that violence against black lesbian women can also be considered as a gender- and a human-rights concern. It also implies that most of the reasons for the endemic gender-based violence against women in South Africa could also apply to black lesbian women. For the

109 Anonymous "Luleki Sizwe Petition Breaks Records: South African Government Yet to Act" 2010 http://africanactivist.org/2010/12/luleki-sizwe-petition-breaks-record.html (accessed 2011-05-05).

110 Underhill "The Tide of Intolerance Must Turn" 2011 Mail \& Guardian http://mg.co.za/article/ 2011-05-13-the-tide-of-intolerance-must-turn (accessed 2011-06-15).

111 According to Tladi Tladi, spokesperson for the Department of Justice quoted in Jadoo "Task Team Set Up to Tackle Homophobic Attacks" 2011 Mail \& Guardian http://mg.co.za/ article/2011-05-04-task-team-set-up-to-tackle-homophobic-attacks (accessed 2011-05-05).

112 Mgudlwa "South Africans Decry Rape of Lesbians" 2011 Mail \& Guardian http://mg. co.za/article/2011-03-15-south-africans-decry-rape-of-lesbians (accessed 2011-03-15).

113 Quoted in Anonymous "Xingwana: End Violence Against Lesbians" 2011 News24 South Africa http://www.news24.com/SouthAfrica/News/Xingwana-End-violence-against-lesbians (accessed 2011-06-22).

114 See the introduction to this article. 
purposes of this submission, we wish to examine the patriarchal nature of South African society, the legacy of apartheid and the assertion that homosexuality is "un-African" as possible reasons for the gender-based violence being perpetrated against black lesbian women.

\section{The patriarchal nature of South African society}

Several prior studies have pointed to the enduring patriarchal nature of South African society as a reason for all forms of gender-based violence towards women. ${ }^{115}$ Studies dealing specifically with gender-based violence against lesbian women have also confirmed this view. ${ }^{116}$ In describing the patriarchal nature of South African society, Jewkes et al state: "men from across the racial spectrum are raised to see themselves as superior to women and taught that men should be tough, brave, strong and respected". ${ }^{117}$ South African women, on the other hand, "are viewed as inferior to men, often as their possessions" ${ }^{118}$ Women in this inferior social position are expected "to conform to gender stereotypes or suffer the consequences". 19 When women challenge these stereotypes through the way they dress and behave, they are at risk in a patriarchal society. This view is confirmed by Parrot and Cummings when they state, "women who challenge the stereotypical assumptions of how they should look may be in danger of punishment ranging from harassment, beatings ... even death". ${ }^{120}$ It is a view that is also confirmed by a statement made in 2006 by Dawn Betteridge, director of the aforementioned Triangle Project: "the problem is largely that of patriarchy ... by adopting the clothing and behaviour typical of the butch lesbian ... [the lesbian woman is perceived as being] ... a threat to masculine dominance". ${ }^{21}$ Elaborating on this threat to "male dominance", Reid and Dirsuweit ${ }^{122}$ opine that "butch" black lesbian women particularly are seen as the "sexual rivals" of men in townships because they are perceived as competing for the affections of the same women and also because they are sometimes more "masculine looking" than men. This, coupled with the fact that they are sexually unavailable to heterosexual men, makes them targets for "corrective rape" and violence. The words of Tshidi, a lesbian survivor of "corrective rape" are most apt: "This guy, he wanted to go out with my girlfriend. So one day he picked me up with a crew of his gangster friends. They took me off the street and to an abandoned place where they beat me with a spanner and did whatever they wanted ... all the time they were telling me, this is what happens when a woman pretends to be a

115 Eg, Vogelman and Eagle 199118 Social Justice 209; Dangor and Hoff 1998 4(2) Violence Against Women 152; and Jewkes et al 2001 91(5) South African Medical Journal 428.

116 Eg, Muholi 200461 Agenda 122; and Nel and Judge 2008 21(3) Acta Criminologica 24.

117 Jewkes et al "Preventing Rape and Violence in South Africa: Call for Leadership in a New Agenda for South Africa" 2009 http://www.mrc.ac.za/gender (accessed 2011-03-25) 1.

118 Jewkes et al 2001 91(5) South African Medical Journal 422.

119 Martin et al "Hate Crimes: The Rise of Corrective Rape in South Africa" 2009 http://www.actionaid.org.uk/doc_lib/correctiveraperep_final.pdf (accessed 2011-12-13) 5.

120 Parrot and Cummings Forsaken Females: The Global Brutalization of Women (2006) 38.

121 Quoted in Anonymous "Murder of Lesbian Sparks Homophobia Concerns" 2006 Mail \& Guardian http://mg.co.za/article/2006-02-21-murderof-lesbian-sparks-homophobic-concerns (accessed 2011-03-24).

122 Reid and Dirsuweit 2002 31(3) Urban Forum 117. 
man". ${ }^{123}$ Moreover, there is an element of envy towards the ambitions, organizational ability and visibility of black lesbians in certain townships. In the words of Phumzile Nkosi, a resident of Vosloorus and a member of the Coalition of African Lesbians, "the local lesbians, unlike the mostly unemployed and lazy men of the area are go-getters, visible and highly organised and not ashamed of who we are ... this makes the men scared and envious of us". ${ }^{24}$

The violence perpetrated against black lesbian women, particularly "corrective rape" and murder, is indicative of the intolerant and "heteronormative" nature of South Africa's patriarchal society. Steyn and Van Zyl define heteronormativity as the "institutionalisation of exclusive heterosexuality in society ... based on the assumption that there only two sexes and that each sex has predetermined gender roles". ${ }^{25}$ Muholi reports that black lesbian women in South African townships who are overtly masculine or "butch" are seen as "disrupting" these prescribed gender roles and the "fixed identity"126 of what it means to be an African woman. Lewis further expands on this view when she states that when African women "step outside the boundaries of what their families, communities and wider society prescribes for them" they are viewed as "challenging their prescribed roles as 'wives, mothers, sisters and daughters". ${ }^{127}$

Deeply embedded in South Africa's heteronormative patriarchal society is a prejudice or bias against lesbian women and homosexual men referred to as "homophobia". Homophobia is said to be "ubiquitous" in South Africa. ${ }^{128}$ While homophobia could manifest in "more subtle forms of victimisation", ${ }^{129}$ such as exclusions, taunting, name-calling and discrimination, its more "heinous manifestation" ${ }^{130}$ would be "corrective rape" and murder.

\section{The legacy of apartheid}

Despite the official demise of the iniquitous apartheid policy in 1994, vestiges of it remain in South African society. Hence poverty, unemployment, the migrant-labour system and gender-based violence towards women remain part of the South African social landscape. Since black South Africans were the most oppressed, marginalized and brutalized by the apartheid policies, black men particularly saw themselves as

${ }^{123}$ Tshidi quoted in Martin et al "Hate Crimes: The Rise of Corrective Rape in South Africa" 2009 http://www.actionaid.org.uk/doc_lib/correctiveraperep_final.pdf (accessed 2011-12-13) 12.

124 Phumzile Nkosi quoted in Taylor "Lesbians in South Africa Continue to Suffer 'Corrective Rape' and Murder" 2011 VOANews http://www.voanews.com/english/news/southern/ lesbians-in-south-africa-con (accessed 2011-05-10).

125 Steyn and Van Zyl The Prize and the Price: Shaping Sexualities in South Africa (2009) 3.

${ }^{126}$ Muholi 200461 Agenda 122.

${ }^{127}$ Lewis "Rethinking Nationalism in Relation to Foucault's History of Sexuality and Adrienne Rich's Compulsory Heterosexuality and Lesbian Experience" 2008 Sexualities 107.

${ }^{128}$ Mkhize et al The Country We Want to Live in: Hate Crimes and Homophobia in the Lives of Black Lesbian South Africans 20.

${ }_{129} \mathrm{Nel}$ and Judge 2008 21(3) Acta Criminologica 22.

${ }^{130}$ Parrot and Cummings Forsaken Females: The Global Brutalization of Women 41. 
"impotent" and vented their frustrations in "dominating women". ${ }^{131}$ Dangor and Hoff further submit that "powerless working-class black men, living ... under the worst economic and social conditions ... take out their frustrations on even more powerless black women". ${ }^{132}$ This could possibly explain why black men perpetrate most of the "corrective" rapes of black lesbian women in townships in South Africa. Research has also shown that women in poorer areas with less home security, public safety and few options to relocate owing to financial constraints are more susceptible to gender-based violence. ${ }^{133}$ This could perhaps explain why black lesbian women living in under-resourced, unsafe, poorer townships are susceptible to gender-based violence. It could also explain why white lesbian women who live in betterresourced, safer areas are almost never the victims of "corrective rape", murder or assault. Muholi aptly sums up the situation with regard to black lesbian women in present-day South Africa: "for the majority of black lesbians .... the everyday lived experience of black majority rule and democracy is still dominated by violent forms of homophobia ... and the lack of access to adequate and affordable housing, healthcare, education and jobs ... we continue to live on the margins of society". ${ }^{134}$

Moreover, since apartheid categorized and discriminated against people, it led to the production of "otherness" and a "discriminatory mindset" in South African society ${ }^{135}$ directed at those who are different and do not conform. One of the major legacies of apartheid, therefore, is intolerance towards those who are different, be it on the basis of race, ethnicity, nationality or sexual orientation. This manifests today in race-related crimes, xenophobic attacks on foreigners (as South Africa witnessed in 2008 when over 60 foreigners were killed and yet again in 2011 when foreign business owners were intimidated in several townships), ${ }^{136}$ and the murder and "corrective rape" of black lesbian women.

\section{The assertion that homosexuality is "un-African"}

In the recent past, several African leaders, whose roles in the liberation of their countries from colonial rule are indisputable, have asserted that homosexuality is "un-African". These leaders include President Robert Mugabe of Zimbabwe, erstwhile President Sam Nujoma of Namibia and President Yoweri Museveni of Uganda. ${ }^{137}$ According to Lewis, one reason for these verbal attacks on homosexuals is that African citizenship and

131 Vogelman and Eagle 199118 Social Justice 214.

132 Dangor and Hoff 1998 4(2) Violence Against Women 127.

${ }^{133}$ Mkhize et al The Country We Want to Live in: Hate Crimes and Homophobia in the Lives of Black Lesbian South Africans 20.

134 Muholi "Mapping Our Histories: A Visual History of Black Lesbians in Post Apartheid South Africa" 2010 http://www.zanelemuholi.com (accessed 2011-15-03) 7.

135 Nel and Judge 2008 21(3) Acta Criminologica 21.

136 Karrim "Local Leaders behind Xenophobic Attacks" 2009 http://mg.co.za/article/2009-03-11 local-leaders-behind-xenophobic-attacks (accessed 2011-10-11).

137 In a recent report by Ollis "Africa Heads Gay Backlash" 2011 Mail \& Guardian http://mg. co.za/article/2011-09-09-africa-heads-gay-backlash (accessed 2011-11-10) Mugabe is quoted as stating that homosexuals were lower than pigs and dogs because at least pigs and dogs knew their female partners and did not have sexual liaisons with pigs of the same sex. 
nation building have been premised on the family, on "natural reproduction of communities" and "natural sexual roles to play". ${ }^{138}$ When these roles are challenged, especially by African women, they are considered "un-African", "westernized" and "traitorous". ${ }^{139}$ One example of such homophobic behaviour by a South African government official dates from 2010, when the erstwhile South African Minister of Arts and Culture attended a photographic exhibition depicting lesbian couples and described it as "immoral, offensive and going against nation-building". ${ }^{140}$ A "corrective-rape" survivor aptly opined: "You as a woman have a role to be a wife, mother and subordinate to your husband ... if you are a lesbian you are not fulfilling these roles". ${ }^{141}$ Muholi similarly states that despite the fall of apartheid and the rise of "Black nationalism ... our lesbian visibility and voices continue to remain on the margins". ${ }^{142}$ In fact, in several South African articles, the "un-Africanness" of black lesbian women has been cited as the reason for the violent attacks against them. ${ }^{143}$ According to Nel and Judge, these African examples of hate speech directed at lesbian women "create the breeding ground for hate based attacks and may be used to justify hate crimes" ${ }^{\text {"144 }}$ such as murder and "corrective rape".

Phillips avers that heterosexual marriage is prized in African culture because of its "economic and reproductive implications", ${ }^{45}$ which manifest in the payment of a dowry (referred to as a "bride price" or "Iobola" in South African parlance) and the production of grandchildren, ensuring the continuation of a family, the family name and bloodline.

Despite its liberal laws relating to same-sex relationships and a number of Constitutional protections, the government's stance in post-apartheid, democratic South Africa is in fact contradictory. An example was the appointment by the South African government of and support for former newspaper columnist, Jon Qwelane, as South Africa's ambassador to Uganda. In 2008 Qwelane wrote a homophobic article in the Sunday Sun ${ }^{146}$ which criticized the legalization of gay and lesbian marriages ${ }^{147}$ and

138 Lewis 2008 Sexualities 107.

139 Ibid.

140 Quoted in Taylor "Lesbians in South Africa Continue to Suffer 'Corrective rape' and Murder" 2011 VOANews http://www.voanews.com/english/news/africa/southern/lesbians-in-southafrica (accessed 2011-05-10).

141 Kekeletso Khena quoted in Mufweba "Corrective Rape Makes You an African Woman" 2003 The Star http://www.iol.co.za (accessed 2011-03-09).

142 Muholi "Mapping Our Histories: A Visual History of Black Lesbians in Post Apartheid South Africa" 2010 http://www.zanelemuholi.com (accessed 2011-15-03).7.

143 Eg, Reddy et al 2007 5(1) HSRC Review 10; and Harrison "South African Gangs use Rape to Cure Lesbians" 2009 http://www.reuters.com/article (accessed 2011-03-09).

144 Nel and Judge 200821 (3) Acta Criminologica 22.

145 Phillips "The Invisible Presence of Homosexuality: Implications for HIV/Aids and Rights in Southern Africa" in Kalipeni, Cradock, Oppong and Ghosh (eds) HIV and Aids in Africa: Beyond Epidemiology (2004) 155161.

146 Qwelane "Call Me Names but Gay is Not OK" 2008 Sunday Sun http://mg.co.za/ uploads/sundaysunmau.pdf (accessed 2011-07-30).

147 Anonymous "Gay Community Slams Qwelane's Shocking Article" 2008 Mail \& Guardian http://mg.co.za/article/2008-07-25-gay-community-protests-qwelane's-shocking-article (accessed 2011-06-15) 
"equated the practice of homosexuality to bestiality". ${ }^{148}$ The South African Equality Court found Qwelane guilty of hate speech in May 2011, ordering him to pay R100 000 to the South African Human Rights Commission and offer an apology to the lesbian/gay/bisexual and transgender community. ${ }^{149}$ However, in August 2011 this ruling was overturned on appeal by the Johannesburg Magistrates Court because the Equality Court had erred in passing judgment on the matter at what should have been only a simple procedural hearing. ${ }^{150}$ Despite the opposition Democratic Alliance's calls for the removal of Qwelane from his position as ambassador, since "South Africa needed to be able to represent its principles of human rights and respect for all", ${ }^{151}$ at the time of writing Qwelane remained in the position.

While lesbian women may be considered "westernized" and "un-African" in present-day Africa, there is some evidence that same-sex practices are not in fact a Western import, and existed in Africa prior to colonization. According to Morgan and Wieringa, one example of these same-sex practices was "women marriages that occurred between powerful women such as rain queens and ... sangomas". ${ }^{152}$ They also aver that it was only with the arrival of the colonialists and Christian missionaries that same-sex practices were deemed "unchristian" or immoral, and subsequently outlawed. ${ }^{153}$ Phillips also avers that "proselytizing settlers ... administered their morality through law, criminal justice and religious conviction" and altered and outlawed same-sex practices. ${ }^{154}$ This view is also shared by Donna Smith, the erstwhile head of the Forum for the Empowerment of Women, who opined: "What is un-African is homophobia ... some people believe homosexuality is an idea brought here by the white man ... but it has always been here ... what the white man brought was homophobia clothed in religious doctrines that we did not have before". ${ }^{155}$ Lamentably, this colonial mindset has been perpetuated in post-colonial, democratic Africa.

148 Anonymous "SAHRC to Consider Complaint Against Qwelane" 2008 Mail \& Guardian http://mg.co.za/article/2008-07023-sahrc-to-consider-complaint-against-qwelane (accessed 2011-06-15)

149 Anonymous "Jon Qwelane Guilty of Hate Speech" 2011 Mail \& Guardian http://mg.co.za/ article/2011-05-31-jon-qwelane-guilty-of-hate-speech (accessed 2011-06-15).

150 Child "Qwelane Ruling Set Aside on a Technicality" 2011 http://mg.co.za/article/2011-09-02qwelane-ruling-set-aside-on-technicality (accessed 2011-09-20).

151 Anonymous "DA Calls for Removal of Qwelane as Ambassador to Uganda" 2011 http://mg.co.za/article/2011-01-31-da-calls-for-removal-of-qwelane-as-ambassador-to (accessed 2011-06-15)

152 Morgan and Wieringa Tommy Boys, Lesbian Men and Ancestral Wives: Female Same-Sex Practices in Africa 17. "Rain queens" in South Africa refer to a dynasty of queens from the Balobedu tribe who live in the northeastern Limpopo region of the country. They are said to have rain-making powers and were not allowed to marry men, Wines "Rain Queen is Dead but Debate over her Power lives on" 2005 NYTimes http://www.nytimes.com/2005/06/21/ international/africa/21rainqueen.html (accessed 2011-08-28). A sangoma is a Zulu traditional healer Puckree, Mkhize, Mgobhozi and Johnson "African Traditional Healers: What Health Care Professionals Need to Know" 2002 25(4) International Journal of Rehabilitation Research 247. Most sangomas in South Africa are women.

153 Morgan and Wieringa Tommy Boys, Lesbian Men and Ancestral Wives: Female Same-Sex Practices in Africa 17.

154 Phillips in HIV and Aids in Africa: Beyond Epidemiology 161.

155 Quoted in Leonard "Fear and Violence still Rule Gay Township Life" 2006 http://mg.co.za/printformat/single/2006-11-06-fear-and-violence-still-rule-gay-township (accessed 2011-10-12) 


\section{Conclusions (Part 1)}

"Corrective rape": almost all the known cases of "corrective rape" in South Africa (in reported cases, media and anecdotal reports) have been perpetrated against black lesbian women and schoolgirls. These rapes are most frequently committed in black townships of South Africa. All the perpetrators of these rapes were black men who knew their victims, and were either friends, relatives, residents or gang members from the same township. The complicity of some lesbians' families in organizing the rapes has been suggested, with male members of the extended family committing the rapes. "Corrective rape" often results in pregnancy, infection with the HIvirus and serious psychological problems.

A culture of not reporting "corrective rape" to the police: most cases of "corrective rape" are not reported to the police. One of the reasons for this culture of non-reporting is the fear of and lack of trust in the South African police. It has been suggested that the police service, as an essential service provider within the criminal-justice system, is homophobic and unsympathetic to lesbian victims of crime. Since "corrective rapes" are not reported to the police, cases cannot be processed and prosecuted by the state. There is also evidence from the two cases that have been to trial that the police conduct poor investigations. The complicity of the police in assisting perpetrators to escape justice occurred in one case.

Murder: all the known cases of murder of lesbian women in South Africa (in reported cases, media and anecdotal reports) have been perpetrated against black lesbians by black men. These murders occur most frequently in black townships of South Africa. The murders are often preceded by acts of "corrective rape", and other acts of extreme violence (torture, stoning and mutilation). Only two of these cases have thus far been to trial. Both cases have been resolved. The swift resolution of one of the cases was ostensibly due to the high-profile status of the victim, who was a soccer player on the national women's soccer team. The second case took almost five years to resolve.

The victims of "corrective rape" and murder: almost all the known victims of "corrective rape" and murder were masculine or "butch" black lesbian women. Many of these victims were overt about their sexuality and highly visible in their local communities, often undertaking work as activists and campaigners for equal rights in their respective townships.

Other crimes and abuses: the limited research based on studies conducted in one province of South Africa has shown that verbal abuse is the most common form of abuse experienced by lesbian women of all races in South Africa. However, this type of abuse is rarely reported to the police and seems to affect white lesbians more than black lesbians. Assault and physical abuse are the second most common form of abuse suffered by lesbian women of all races. However, more black than white lesbians attested to this form of abuse. Two black lesbians attested to having been abducted and a small percentage of all lesbian women attested to having been robbed. The limited research conducted on black lesbian schoolgirls has revealed that they are often forced to leave school because of an intolerant, discriminatory school environment. 
The law: while hate speech has been criminalized in South Africa, no other specific hate-crime legislation exists. In jurisdictions which do recognize hate crimes, hate-crime laws would have been applicable to the cases of "corrective rape" and murder committed with a hate/bias/orientation motive. ${ }^{156}$ The lack of hate-crime legislation in South Africa is a further reason for the lack of reliable statistics and quantifiable data on the phenomenon of "corrective rape" and murder of lesbian women in South Africa.

The government's response: until 2011 the South African government's response to the issue of violence against lesbian women has been negligible. The plight of lesbian women has been largely ignored despite calls from the civil-society organization sector from 2002 for the government to take action. The formation of the government task team in 2011 is a positive development, but there is no certainty as to whether the task team will recommend and implement a co-ordinated response or new policies, amend existing legislation or perhaps propose new hate crime legislation.

Any progress in the battle against the scourge of violence against lesbian women in South Africa has been the result of grassroots activism. Most of this activism has been in the form of activist work by civil-society organizations in black townships. In the face of government inaction, the launch of the 07-07-07 Campaign is a positive example of co-operation between civil-society organizations with a lesbian/gay/bisexual and transgender agenda to present a co-ordinated response. The occasional printmedia coverage that violence against lesbian women has received has also contributed to some extent to create awareness of the problem.

156 Examples of such legislation are the Criminal Justice Act of 2003 in the United Kingdom, which enables a court to impose an increased sentence in cases where the crime was related to sexual orientation, and the Matthew Shephard and James Byrd, Jr. Hate Crimes Prevention Act of 2009 in the USA, which extended American federal law to apply to crimes motivated by the victim's actual or perceived sexual orientation and gender identity. 